\title{
Pengaruh Range Of Motion Aktif terhadap Pemulihan Kekuatan Otot dan Sendi Pasien Post Op Fraktur Ekstremitas di Wilayah Kerja Puskemas Muara Kumpeh
}

\author{
Rino $\mathbf{M}^{1}$, Jufri Al Fajri ${ }^{2}$ \\ ${ }^{1,2}$ Program Studi Profesi Ners, Sekolah Tinggi Ilmu Kesehatan Baiturrahim Jambi \\ Email : Rino.malvino20@yahoo.com
}

Submitted : 11/01/2021

Accepted: 10/09/2021

Published: 15/09/2021

\begin{abstract}
Fracture is a break in bone continuity and is determined according to its type and extent (Anita, 2015). Fractures caused by injuries include falls, traffic accidents and trauma to sharp or blunt objects. The trend of injury prevalence shows an increase from $7.5 \%$ in 2017 to $8.2 \%$ in 2018 (Kemenkes RI, 2018). This research is a quantitative research with pre-experimental research methods with one group pretest and posttest research design. This study was conducted to determine the effect of restoring muscle and joint strength in post-op patients with limb fracture in the working area of Muara Kumpeh puskemas. The research time is planned to be carried out on July 15, 2020 in the working area of the Muara Kumpeh Health Center. The population in this study was Post op fracture with a number of 84 people. The sample in this study was 15 people using purposive sampling method. Data collection was carried out by observing the respondents MMT (Manual Muscle Testing). research using the T-Test. The results showed that the average value of muscle and joint strength recovery in post-op limb fracture patients before therapy was 30.20 Mean while the average value of muscle and joint strength recovery in post-op limb fracture patients after being given therapy was 35.80 and the results showed The effect of restoring muscle and joint strength in post-op limb fracture patients in the working area of Muara Kumpeh Health Center with $p$-value $(0,000)<\alpha=0.05$. The conclusion of this study is the importance of ROOM therapy in post-op expression fracture patients. It is hoped that it can be used for patients to improve muscle strength systems and better recovery of mobilization activities.
\end{abstract}

Keywords: fracture, , patiens, ROM

\section{Abstrak}

Fraktur adalah terputusnya konstinuitas tulang dan ditentukan sesuai jenis dan luasnya (Anita, 2015). Kasus fraktur yang disebabkan oleh cedera antara lain karena terjatuh, kecelakaan lalu lintas dan trauma benda tajam atau tumpul. Kecenderungan prevalensi cedera menunjukkan kenaikan dari 7,5\% pada tahun 2017 menjadi 8,2\% pada tahun 2018 (Kemenkes RI, 2018).Penelitian ini merupakan penelitian kuantitatif dengan metode penelitian pre eksperiment dengan desain penelitian one group pretest dan posttest. Tujuan Penelitian ini untuk mengetahui Pengaruh pemulihan kekuatan otot dan sendi pasien post op fraktur ekstremitas di Wilayah kerja puskemas Muara Kumpeh. Waktu penelitian di lakukan pada bulan Juli 2020 di wilayah kerja puskemas muara kumpeh. Populasi adalah pasien Post op Fraktur dengan jumlah 84 orang. Sampel dalam penelitian adalah 15 orang dengan menggunakan metode pengambilan sampel Purposive Sampling.Pengumpulan data dilakukan dengan observasi MMT (Manual Muscle Testing) kepada responden. Penelitian menggunakan uji T-Test Hasil penelitian di ketahui bahwa nilai rata-rata pemulihan kekuatan otot dan sendi pasien post op fraktur ekstremitas sebelum diberikan terapi adalah 30.20 Mean sedangkan nilai rata-rata pemulihan kekuatan otot dan sendi pasien post op fraktur ekstremitas sesudah diberikan terapi adalah 35.80 dan hasil penelitian menujukan ada Pengaruh pemulihan kekuatan otot dan sendi pasien post op fraktur ekstremitas di Wilayah kerja puskemas Muara Kumpeh dengan $p$-value $(0,000)<\alpha=0,05$. Kesimpulan dari penelitian ini yaitu pentingnya terapi ROOM pada pasien Post Op Fraktur Ekstermitas diharapkan dapat digunakan bagi pasien meningkat sistem kekuatan otot dan pemulihan aktivitas mobilisasi lebih baik.

Kata kunci: fraktur, pasien, $\mathrm{ROM}$ 


\section{PENDAHULUAN}

Pembedahan atau operasi merupakan tindakan pengobatan dengan menggunakan teknik invasif dimana dilakukan sayatan pada bagian tubuh yang akan ditangani dan diakhiri dengan penutupan dengan jahitan luka. Tindakan pembedahan bertujuan untuk menyelamatkan nyawa, mencegah kecacatan dan komplikasi (Safitri, 2015).

Data World Health Organization (WHO) (2018) menunjukkan bahwa selama lebih dari satu abad perawatan bedah sudah menjadi komponen penting dari perawatan kesehatan di seluruh dunia.Diperkirakan 234,2 juta prosedur operasi dilakukan setiap tahun (Safitri, 2018). Tindakan pembedahan atau operasi terbanyak di rumah sakit seluruh dunia adalah akibat insiden kecelakaan, yaitu operasi fraktur dengan persentase $35,6 \%$ dan sisanya operasi kasus lainnya.

Fraktur adalah terputusnya konstinuitas tulang dan ditentukan sesuai jenis dan luasnya (Anita, 2015). Fraktur dibagi atas fraktur terbuka dan fraktur tertutup. Fraktur terbuka merupakan suatu fraktur dimana terjadi hubungan dengan lingkungan luar melalui kulit. Fraktur tertutup adalah fraktur dimana kulit tidak tertembus oleh frakmen tulang, sehingga tempat fraktur tidak tercemar oleh lingkungan diluar kulit (Permana, 2015).

Fraktur di Indonesia menjadi penyebab kematian terbesar ketiga di bawah penyakit jantung koroner dan tuberculosis. Kasus fraktur yang disebabkan oleh cedera antara lain karena terjatuh, kecelakaan lalu lintas dantrauma benda tajam atau tumpul. Kecenderungan prevalensi cedera menunjukkan kenaikan dari 7,5 \% pada tahun 2017 menjadi 8,2\% pada tahun 2018 (Kemenkes RI, 2018).

Di Indonesia angka operasi fraktur hingga akhir tahun 2017 telah mencapai 27,9\% dari total keseluruhan jenis operasi. Prevalensi fraktur yang cukup tinggi yaitu insiden fraktur pada ekstremitas yakni sekitar 46,2\% (Depkes RI, 2017). Hal ini dibuktikan dengan adanya kecenderungan peningkatan tindakan operasi bedah bagian ekstremitas di beberapa rumah sakit dari tahun ke tahun, yakni sekitar delapan juta orang mengalami kejadian fraktur ekstremitas dengan jenis fraktur yang berbeda dan penyebab yang berbedayang dapat terjadi pada tulang lengan atas, lengan bawah, tungkai atas, tungkai bawah, tangan dan kaki (Windiarto, 2016).

Berdasarkan 34 Provinsi yang ada di Indonesia, tindakan operasi fraktur ekstremitas paling tinggi ada pada Provinsi Bali (3.065), disusul setelahnya DKI Jakarta (2.780), Jawa Timur (2.655), Jawa Tengah (2.576) dan Jambi (2.443) (Depkes RI, 2018). Dari 19 Kabupaten/Kota yang ada di Jambi, Kota Jambi merupakan daerah yang persentase rumah sakitnya paling banyak melakukan tindakan operasi fraktur ekstremitas (20,3\%), disusul setelahnya Dharmasraya $(16,2 \%)$ dan Pasaman Barat $(11,5 \%)$ yang telah mengalami kenaikan $1,3 \%$ bila dibandingkan dengan tahun sebelumnya (Riskesdas, 2018).

Banyak dampak negatif dari kejadian fraktur ekstremitas. Menurut Oktasari (2013), dari 2.700 orang mengalami insiden fraktur ekstremitas, $56 \%$ penderita mengalami kecacatan fisik, 24\% mengalami kematian, $15 \%$ mengalami kesembuhan dan 5\% mengalami gangguan psikologis atau depresi terhadap adanya kejadian fraktur. Kerusakan frakmen tulang ekstremitas memberikan menifestasi pada hambatan mobilisasi fisik dan akan diikuti dengan adanya spasme otot yang memberikan menifestasi deformitas pada ekstremitas yaitu pemendekan, apabila kondisi ini berlanjut tanpa dilakukan intervensi yang optimal maka akan memberikan risiko terjadinya malunion pada tulang yang mengalami fraktur tersebut.

Menggunakan pengujian otot dan sendi secara manual yang disebut dengan MMT (Manual Muscle Testing). Pemeriksaan ini bertujuan untuk mengetahui kemampuan otot dan sendi mengkontraksikan kelompok otot sendi secara volunter. Metode MMT menggunakan skala 0-5. Skala 0 jika Tidak ada gerakan otot sama sekali, skala 1 jika Ada kontraksi saat palpasi tetapi tidak ada gerakan yang terlihat, skala 2 jika Ada gerakan tetapi tidak dapat melawan gravitasi, skala 3 jika dapat bergerak melawan gravitasi, skala 4 jika dapat bergerak melawan tahanan pemeriksa tetapi masih lemah dan skala 5 jika dapat bergerak dan melawan tahanan pemeriksa dengan kekuatan penuh. (Kozier et al, 1995 dalam Ananda, Usyaira, 2016).

Penatalaksanaan non farmakologi yaitu fisioterapiuntuk mengurangi nyeri dan mempertahankan atau meningkatkan kekuatan otot dan sendi yaitu dengan Range of Motion 
(ROM). ROM merupakan salah satu indikator fisik yang berhubungan dengan fungsi pergerakan. Menurut Insiyah (2015), ROM dapat diartikan sebagai pergerakan maksimal yang dimungkinkan pada sebuah persendian tanpa menyebabkan rasa nyeri. ROM merupakan kegiatan yang penting dalam pemulihan kekuatan otot dan sendi post operasi untuk mencegah komplikasi lebih lanjut

Menurut Potter \& Perry (2005) dalam Oktasari (2013), pada kondisi post op fraktur ekstremitas, seseorang tidak mampu melakukan aktivitas karena keterbatasan gerak, maka kekuatan otot dapat dipertahankan melalui penggunaan otot yang terus-menerus, salah satunya melalui mobilisasi persendian dengan latihan rentang gerak sendi atau ROM. Latihan ROM adalah latihan yang dilakukan untuk mempertahankan atau memperbaiki tingkat kesempurnaankemampuan menggerakkan persendian secara normal dan lengkap untuk meningkatkan massa otot dan tonus otot (Potter \& Perry, 2005 dalam Wiharja, 2016).ROM adalah latihan yang memungkinkan terjadinya kontraksi dan pergerakan otot, dimana klien menggerakkan masing- masing persendiannya sesuai gerakan normal baik secara aktif ataupun pasif (Ridha \& Putri, 2015).

Hasil penelitian Murtaqib (2013), terdapat perbedaan antara rentang gerak atau kekuatan otot dan sendi pada ROM pasif dan ROM aktif di wilayah kerja Puskesmas Tanggul Kabupaten Jember $(\mathrm{p}=0.001)$. Penelitian Purwanti (2015) didapatkan hasil ada pengaruh signifikan pada latihan ROM aktif terhadap kekuatan otot pada pasien post operasi fraktur humerus di RSUD Dr. Moewardi dengan hasil $\mathrm{p}$ value $=0,000$. Selanjutnya penelitian Mintarsih (2015) juga didapati bahwa ada pengaruh ROM aktif terhadap kemampuan fungsi ektremitas sendi lutut pada pasien post operasi fraktur femur $(\mathrm{p}=0,00)$.

ROM aktif lebih memberikan pengaruh dibandingkan ROM pasif sebesar 3,2x. hal ini dikarenakan pada ROM aktif pasien dapat lebih sering dan mandiri dalam melakukan latihan dengan nyaman serta terhindar dari rasa nyeri. Anita (2018) juga mengatakan bahwa mobilisasi dini dengan ROM aktif adalah salah satu faktor kunci dalam perawatan pasien post operasi fraktur ekstremitas.

Menurut Usyaira (2015), melakukan tindakan ROM aktif pada pasien post operasi fraktur ekstremitas sangat mempengaruhi dengan tingkat kesembuhan pasien. Dilakukannya ROM secara rutin dapat mempertahankan mobilitas sendi dan jaringan ikat, meminimalisir efek dari pembentukan kontraktur, mempertahankan elastisitas mekanis dari otot, membantu kelancaran sirkulasi, meningkatkan pergerakan sinovial untuk nutrisi tulang rawan serta difusi persendian, menurunkan atau mencegah rasa nyeri, membantu proses penyembuhan pasca cedera dan operasi dan membantu mempertahankan kesadaran akan gerak dari pasien. Untuk mendapatkan hasil yang maksimal, ROM harus diulang sekitar 8 kali dan dikerjakan minimal 2 kali sehari selama minimal 3 hari berturut-turut dan dapat dilakukan hari ke 2 setelah operasi.

Berdasarkan studi pendahuluan yang dilakukan oleh mewawancarai 5 orang pasien post operasi fraktur ekstremitas, didapati bahwa 3 dari 5 orang pasien mengatakan masa pemulihan setelah operasi terasa lambat, lebih dari 3 hari ekstremitas bekas operasi baru dapat digerakkan. 2 dari 5 orang pasien mengatakan tidak melakukan ROM aktif, Latihan ROM hanya dilakukan saat ada perawat yang membantu saja.Berdasarkan hasil observasi yang dilakukan oleh peneliti di hari yang sama, peneliti juga menemukan bahwa belum ada satupun pasien melakukan ROM aktif (mandiri). 3 dari 5 orang pasien memiliki kekuatan sendi dan otot dengan rentang nilai 1 (skala 0-5).

Berdasarkan latar belakang dan fenomena yang ditemukan oleh peneliti, maka peneliti tertarik untuk melakukan penelitian yang berjudul "Pengaruh range of motion aktif terhadap pemulihan kekuatan otot dan sendi pasien post op fraktur ekstremitas di Wilayah kerja puskemas Muara Kumpeh".

\section{METODE PENELITIAN}

Penelitian ini merupakan penelitian kuantitatif dengan rancangan /desain penelitian quasi eksperimentone group pre test post test. Penelitian ini akan dilakukan di Kota Jambi pada Bulan Januari 2020. Populasi dalam penelitian ini adalah seluruh pasien post op fraktur ekstremitasdi Wilayah Kerja Puskemas Muara Kumpeh pada bulan Januari 2020 dengan populasi 84 jumlah 15 Sampel. Tehnik pengambilan sampel Purposive Sampling. Metode pengumpulan data dilakukan dengan pengukuran tekanan darah 
lansia sebelum dan sesudah diberikan intervensi. Uji statistik yang digunakan jika data berdistribusi normal adalah dengan ujiPaired Sample T Test (T Dependen). Namun jika data tidak normal, maka peneliti menggunakan uji wilcoxon. Tingkat kemaknaan dalam penelitian adalah $95 \%(\alpha=0,05$ atau $5 \%$ ). Dikatakan ada pengaruh jika p_value $\leq$ 0,05 dan tidak ada pengaruh jika p_value $>0,05$.

\section{HASIL DAN PEMBAHASAN}

Tabel 1. Jumlah Range of motion pada pasien pemulihan kekuatan otot dan sendi pasien post op fraktur ekstremitas Sebelum Dan Sesudah Diberikan Terapi (Pre-Test Dan Post-Test)

\begin{tabular}{cccc}
\hline No & Skor Pre-Test & Skor Post-Test & Selesih \\
\hline 1 & 31 & 36 & 5 \\
2 & 28 & 35 & 3 \\
3 & 30 & 36 & 6 \\
4 & 31 & 36 & 5 \\
5 & 30 & 35 & 5 \\
6 & 29 & 35 & 6 \\
7 & 29 & 37 & 8 \\
8 & 32 & 37 & 5 \\
9 & 30 & 36 & 6 \\
10 & 30 & 34 & 4 \\
11 & 30 & 36 & 6 \\
12 & 30 & 35 & 5 \\
13 & 30 & 34 & 4 \\
14 & 32 & 38 & 6 \\
15 & 31 & 37 & 6 \\
T & 453 & 537 & 80 \\
R & 30,20 & 35,80 & \\
\hline
\end{tabular}

Dari tabel 1. di atas dapat diketahui bahwa nilai rata-rata Range of motionpada pasien pemulihan kekuatan otot dan sendi pasien post op fraktur ekstremitas Sebelum diberikan terapi adalah 30,20 sedangkan nilai rata-rata Range of motionpada pasien pemulihan kekuatan otot dan sendi pasien post op fraktur ekstremitas sesudah diberikan pendidikan kesehatan adalah 35,80.

Berdasarkan hasil penelitian Reni (2014) rata-rata fleksibilitas fleksi sendi panggul adalah 45.5 derajat dengan rentang tertinggi adalah 50 derajat dan terendah adalah 40 derajat.Rata-rata fleksibilitas fleksi sendi lutut adalah 15.5 dengan rentang tertinggi 20 derajat dan terendah 10 derajat. Dan rata-rata fleksibilitas dorsofleksi adalah 1.5 derajat dengan rentang tertinggi 5 dan terendah 0 derajat, sedangkan rata-rata fleksibilitas plantarfleksi adalah 33.5 derajat dengan rentang tertinggi 45 derajat dan terendah 25 derajat.

Fraktur adalah terputusnya kontinuitas jaringan tulang dan / atau tulang rawan yang umumnya disebabkan oleh rudapaksa (Sjamsuhidajat, 2015). Fraktur femur adalah suatu patahan pada kontinuitas struktur tulang paha yang ditandai adanya deformitas yang jelas yaitu pemendekan tungkai yang mengalami fraktur dan hambatan mobilitas fisik yang nyata (Muttaqin, 2013). Fraktur dapat terjadi akibat peristiwa trauma langsung, tekanan yang berulang-ulang, dan kelemahan abnormal pada tulang (fraktur patologik) (Salamon, 2010).

Fraktur terbagi atas fraktur komplet, fraktur tidak komplet, fraktur tertutup, fraktur terbuka, dan fraktur patologis. Fraktur bisa terjadi didaerah cranium, thorak, pelvis, anggota gerak atas, dan anggota gerak bawah. Prinsip penanganan fraktur meliputi reduksi, imobilisasi, pengembalian fungsi, dan kekuatan normal dengan rehabilitasi. Reduksi dapat dilakukan secara terbuka maupun tertutup. Reduksi terbuka (open reduksi) dilakukan melalui pembedahan dengan cara memasukkan alat fiksasi berupa plat, screw, wire atau pin kedalam tulang. Fiksasi dapat dilaksanakan secara interna maupun ekterna, tergantung dari bentuk frakturnya (Smeltzer \& Bare, 2012).

Kondisi perkembangan kekuatan otot dan sendi pasien akan berdampak pada lama perawatan. Waktu perawatan Length of stay (LOS) merupakan salah satu indikator penilaian dalam akreditasi sebuah rumah sakit. Semakin lama length of stay maka penilaian terhadap rumah sakit tersebut semakin buruk. Dampak negatif lain yang diakibatkan lamanya pemulihan kekuatan otot dan sendi pasien pasca operasi menyebabkan pasien harus berlamalama dalam posisi tirah baring. Posisi tirah baring yang lama akan meningkatkan terjadinya komplikasi yang serius seperti pembentukan suatu thrombus sehingga aliran balik vena mengalami hambatan (Windiarto, 2016).

Faktor pemulihan kekuatan otot dan sendi bagi pasien post op fraktur ekstremitas dapat dilakukan dengan penatalaksanaan farmakologi dan non farmakologi. Penatalaksanaan secara farmakologi dapat dilakukan dengan cara pemberian obat-obatan. Obat farmakologi dapat memberikan efek samping yang jika konsumsi secara berlebihan 
maka akan menimbulkan terjadinya retensi cairan, alergi dan aritmia jantung. Upaya untuk meminimalkan efek samping farmakologis, maka perlu pendekatan nonfarmakologis (Nuraini, 2016).

Menurut teori yang dikemukakan oleh Smeltzer (2012), latihan rentang gerak bertujuan untuk mempertahankan fleksibilitas dan mobilitas sendi, mengembalikan kontrol motorik, meningkatkan/ mempertahankan integritas sendi dan jaringan lunak, membantu sirkulasi dan nutrisi sinovial dan menurunkan pembentukan kontraktur terutama pada ekstremitas yang mengalami paralisis. Manfaat lain yang didapatkan dari latihan rentang gerak yaitu dapat memaksimalkan fungsi aktifitas kehidupan sehari-hari, mengurangi atau menghambat nyeri, mencegah bertambah buruknya sistem neuromuscular, mengurangi gejala depresi dan kecemasan, meningkatkan harga diri, meningkatkan citra tubuh dan memberikan kesenangan.

Muscle spindle merupakan suatu receptor yang menerima rangsang dari regangan otot. Regangan yang cepat akan menghasilkan impuls yang kuat pada muscle spindle. Rangsangan yang kuat akan menyebabkan refleks muscle spindle yaitu mengirim impuls ke spinal cord menuju jaringan otot dengan cepat, menyebabkan kontraksi otot yang cepat dan kuat. Muscle spindle sangat berperan dalam proses pergerakan atau pengaturan motorik (Potter \& Perry, 2005).

Berdasarkan hasil penelitian, pada klien fraktur mengalami keterbatasan dalam pergerakan, latihan pasif sangat tepat dilakukan dan akan mendapatkan manfaat seperti terhindarnya dari kemungkinan terjadinya gangguan fleksibilitas sendi. Setiap gerakan yang dilakukan dengan rentang yang penuh, maka akan meningkatkan kemampuan bergerak dan dapat mencegah keterbatasan dalam beraktivitas. Ketika pasien tidak dapat melakukan latihan secara aktif maka perawat bisa membantu untuk melakukan latihan.

Tabel 2. Pengaruh range of motion aktif terhadap pemulihan kekuatan otot dan sendi pasien post op fraktur ekstremitas

\begin{tabular}{ccccc}
\hline Variabel & Mean & SD & $\begin{array}{c}p- \\
\text { value }\end{array}$ & $\mathbf{N}$ \\
\hline (Pre test) ROM & 30,20 & 1,082 & 0,000 & 15 \\
(Post test)ROM & 35,80 & 1,146 & & \\
\hline
\end{tabular}

Hasil analisis pada tabel 2 diatas menunjukan bahwa rata - rata range of motion aktifterhadap pemulihan kekuatan otot dan sendi pasien post op fraktur ekstremitas responden sebelum diberikan terapi adalah 30,20 dengan standar deviasi 1,082 sedangkan setelah diberikan terapi rata - rata range of motion aktif terhadap pemulihan kekuatan otot dan sendi pasien post op fraktur ekstremitasSetelah diberikan terapi responden adalah 35,80 dengan standar deviasi 1.146. Hasil uji statistik paired t-test didapatkan nilai $p$-value $=0,000<0,05$ dengan selisih mean 0.553 maka dapat disimpulkan bahwa secara statistik mengalami peningkatan signifikan range of motion aktif terhadap pemulihan kekuatan otot dan sendi pasien post op fraktur ekstremitas.

Hal ini didukung penelitian Murtaqib (2013), terdapat perbedaan antara rentang gerak atau kekuatan otot dan sendi pada ROM pasif dan ROM aktif di wilayah kerja Puskesmas Tanggul Kabupaten Jember $(\mathrm{p}=0.001)$. Penelitian Purwanti (2015) didapatkan hasil ada pengaruh signifikan pada latihan ROM aktif terhadap kekuatan otot pada pasien post operasi fraktur humerus di RSUD Dr. Moewardi dengan hasil $\mathrm{p}$ value $=0,000$. Selanjutnya penelitian Mintarsih (2015) juga didapati bahwa ada pengaruh ROM aktif terhadap kemampuan fungsi ektremitas sendi lutut pada pasien post operasi fraktur femur $(\mathrm{p}=0,00)$.

Fraktur adalah terputusnya kontinuitas jaringan tulang. Fraktur biasa terjadi karena trauma langsung eksternal, tetapi dapat juga terjadi karena deformitas tulang misalnya fraktur patologis karena osteoporosis, penyakit paget dan osteogenesis imperfekta). Secara teori, latihan rentang gerak yang dilakukan secara rutin sangat penting karena tujuan utama latihan rentang gerak adalah untuk memelihara sendi agar tetap fleksibel.Latihan ini juga dapat membantu sendi agar tidak kaku, kontraktur serta menghindari deformitas.Bahaya paling besar ketika terjadi paralisis atau spastis yang menyebabkan ketidakseimbangan otot, dimana sendi tertarik lebih kuat ke satu arah sehingga menekuk secara terus menerus (Werner, 2009). Keadaan ini akan mengakibatkan sendi kehilangan elastisitasnya sehingga fleksibilitas sendi menjadi menurun.

Kontraktur merupakan gangguan yang umum terjadi pada klien dengan pasien fratur 
femur pasca pembedahan. Kontraktur bisa berupa kontraksi otot yang permanen, tahanan yang tinggi pada peregangan pasif, hipoekstensibilitas, berkurangnya rentang peregangan pasif dan pemendekan otot. Untuk mencegah terjadinya kontraktur dan deformitas, latihan rentang gerak harus dilakukan secara kontinyu. Penting bagi pasien fraktur femur terpasang fiksasi interna untuk menggerakan tubuhnya melalui pergerakan sendi secara penuh dalam aktifitas kehidupan sehari-hari (Werner, 2009).

Penatalaksanaan umum fraktur meliputi menghilangkan rasa nyeri, Menghasilkan dan mempertahankan posisi yang ideal dari fraktur, Agar terjadi penyatuan tulang kembali, Untuk mengembalikan fungsi seperti semula. Untuk mengurangi nyeri tersebut, dapat dilakukan dengan pembidaian atau gips. Bidai dan gips tidak dapat pempertahankan posisi dalam waktu yang lama. Untuk itu diperlukan teknik seperti pemasangan traksi kontinu, fiksasi eksteral atau fiksasi internal (Murtaqib, 2013).

Kekuatan otot dan sendi merupakan kekuatan suatu otot atau grup otot dan sendi yang dihasilkan untuk dapat melawan tahanan dengan usaha yang maksimum.Kekuatan otot dan sendi merupakan suatu hal penting untuk setiap orang, karena kekuatan otot merupakan suatu daya dukung gerakan dalam menyelesaikan tugas-tugas. Penurunan fungsi dan kekuatan otot sendi akan mengakibatkan penurunan kemampuan mempertahankan keseimbangan tubuh, hambatan dalam gerak duduk ke berdiri, peningkatan resiko jatuh, perubahan postur (Gontung, 2012).

Latihan rentang gerak dapat diberikan pada pasien yang mengalami keterbatasan mobilisasi, dan tidak mampu melakukan beberapa atau semua latihan rentang gerak dengan mandiri.Untuk itu perawat harus membuat jadwal kapan latihan rentang gerak harus dilakukan. Berdasarkan obsevasi peneliti dilapangan hal-hal yang menghambat dalam danya nyeri pasca pembedahan dan daerah trauma dapat ditepis dengan cara melakukan latihan rentang gerak pasif secara perlahan dan lembut sehingga tidak menimbulkan perasaan nyeri pada pasien. (Potter \& Perry, 2012).

ROM merupakan salah satu indikator fisik yang berhubungan dengan fungsi pergerakan. Menurut Insiyah (2015), ROM dapat diartikan sebagai pergerakan maksimal yang dimungkinkan pada sebuah persendian tanpa menyebabkan rasa nyeri. ROM merupakan kegiatan yang penting dalam pemulihan kekuatan otot dan sendi post operasi untuk mencegah komplikasi lebih lanjut.

Latihan ROM adalah latihan yang dilakukan untuk mempertahankan atau memperbaiki tingkat kesempurnaan kemampuan menggerakkan persendian secara normal dan lengkap untuk meningkatkan massa otot dan tonus otot (Potter \& Perry, 2005 dalam Wiharja, 2016). ROM adalah latihan yang memungkinkan terjadinya kontraksi dan pergerakan otot, dimana klien menggerakkan masing- masing persendiannya sesuai gerakan normal baik secara aktif ataupun pasif (Ridha \& Putri, 2015).ROM kegiatan penting pada periode post operasi guna mengembalikan kekuatan otot pasien (Purwanti, 2013).

Latihan rentang gerak yang diberikan dalam penelitian ini cukup mendapat respon yang baik dari responden, keluarga dan petugas Trauma Centre sendiri. Pelaksanaan latihan rentang gerak ini juga didukung dengan pedoman yang disertai gambar, sehingga memudahkan responden dan petugas untuk melaksanakannya.

\section{SIMPULAN}

Dapat disimpulkan bahwa gambaran sebelum pemulihan kekuatan otot dan sendi pasien post op fraktur ekstremitas di dapatkan nilai rata - rata (30.20) mean. Gambaran setelah diberikan pemulihan kekuatan otot dan sendi pasien post op fraktur ekstremitas di dapatkan nilai rata - rata (35.80) mean. Ada Pengaruh pemulihan kekuatan otot dan sendi pasien post op fraktur ekstremitas di Wilayah kerja puskemas Muara Kumpeht-test $p$-value $=0,000$ $<0,005$.

\section{SARAN}

Disarankan dapat menjadi salah satu program yang ditawarkan dan dikenalkan kepada pasien pemulihan kekuatan otot dan sendi pasien post op fraktur ekstremitas di Wilayah kerja puskemas Muara Kumpehyang terlibat dalam kegiatan tersebut sebagai metode untuk meningkatkan fungsi muskular pada pasien post op sehingg diharapkan pasien bisa beraktifitas. 


\section{DAFTAR PUSTAKA}

Aini, M. (2015). Efektivitas Latihan Range Of Motion (ROM) Bahu terhadap Peningkatan ROM pada Pasien Post Mastektomi di RSUP H. Adam Malik Medan. Jurnal Keperawatan USU. 5(3), 980-997

Anita, F. (2015). Pengaruh Latihan Range of Motion terhadap Rentang Gerak Sendi Ekstremitas Atas pada Pasien Pasca Stroke di Makassar. Journal of Islamic Nursing. 3(1), 97-99.

Bowden, (2018). Pediatric nursing procedures. second edition. Philadelphia: Lipincot William and Wilkins.

Depkes RI (2017). Prevalensi Angka Kejadian Fraktur di Indonesia. Jakarta.

Gontung, A.T. (2012). Orthopaedic dan Traumatology Center di Manado "Sustainable Healthcare Architecture" Jurnal UNSRAT. 4(3), 93-102

Hastono, S. P. \& S. (2011). Statistik Kesehatan (1st ed.). Raja Grafindo Persada. Jakarta.

Insiyah, R. (2015). Petingnya Latihan Gerak pada Pasien Fraktur. Rineka Cipta. Jakarta.

Kemenkes RI (2018). Prevalensi Cidera Akibat Kecelakaan di Indonesia. Jakarta.

Murtaqin, R. (2013). Pengaruh ROM terhadap Pencegahan Kecacatan. Rineka Cipta. Jakarta.

Nuraini, D.S. (2016). Perbedaan Slow Deep Breathing dan Diaphragmatic Breathing Terhadap Penurunan Tekanan Darah pada Pasien Hipertensi di RSUD Ambarawa. Jurnal Ilmu Keperawatan dan Kebidanan (JIKK). 6(2), 1-10.

Oktasari, V. (2013). Pengaruh Pendidikan Kesehatan Terhadap Pelaksanaan Rentang Gerak Sendi Aktif Post Operasi pada Pasien Fraktur Ekstremitas di Ruang Bedah Trauma Center RSUP DR. M. Djamil Padang. Jurnal Ners. 9(2), 94102.

Permana, O. (2015). Pengaruh Range Of Motion (ROM) terhadap Intensitas Nyeri pada Pasien Post Operasi Fraktur Ekstremitas Bawah. Jurnal KEMAS. 2(2), 1327-1334.

Purwanti, R. (2015). Pengaruh Latihan Range Of Motion (ROM) Aktif terhadap Kekuatan Otot Pada Pasien Post Operasi
Fraktur Humerus di RSUD Dr. Moewardi. GASTER. 10(2), 42-52.

Ridha \& Putri. (2015). Pengaruh Latihan Range Of Motion (ROM) Aktif terhadap Kekuatan Otot Ekstremitas Bawah pada Lansia dengan Osteoarthritis di Wilayah Kerja Puskesmas Koni Kota Jambi. Jurnal Akademika Baiturrahim. 4(2), 4552.

Riyanto, A. (2009). Pengolahan Data Kesehatan. Rineka Cipta. Jakarta.

Safitri, U. (2018). Efektifitas ROM Aktif dan Mobilisasi Dini terhadap Kembalinya Peristaltik Usus pada Pasien Post Operasi Abdomen dengan General Anestesi di RSUD Kota Salatiga. Jurnal Ilmu Keperawatan dan Kebidanan (JIKK). $7(2), 67-78$

Sjamsuhidajat, (2015). Buku-ajar ilmu bedah (2nd.). Jakarta: Buku Kedokteran EGC.

Sugiyono. (2013). Metode Penelitian Kuantitatif Kualitatif. Alfabeta. Bandung

Smeltzer, (2012). Buku ajar keperawatanmedikal-bedah brunner \& suddarth (8th, 3rd vol.). Jakarta: Buku Kedokteran EGC

WHO. (2018). Surgery in the World. Philadelpia. Pennsylvania. USA.

Wiharja, W. (2016). Acute Effect of Slow Deep Breathing Maneuver on Patient with Essential Hypertension Stage 1 and 2. Jurnal Kardiologi Indonesia. 37(2), 7580. 